\title{
Lymphocytic gastritis: a newly described entity: a retrospective endoscopic and histological study
}

\author{
J HAOT, L HAMICHI, L WALLEZ, AND P MAINGUET
}

From the Departments of Pathological Anatomy and Gastro-enterology, Université Catholique de Louvain, Brussels, Belgium

SUMMARY Lymphocytic gastritis is a histopathological entity characterised by the accumulation of small lymphocytes in the surface and foveolar epithelium. In order to investigate the correlation between endoscopy and histology in this condition, 192 observations selected on the basis of a presumed diagnosis of erosive or varioliform gastritis were reviewed. Ninety two instances corresponded to lymphocytic gastritis, while 100 did not show any particular microscopic feature and were labelled non-specific gastritis. There was a good correlation (48 of 58) between the diagnosis of the so-called varioliform gastritis and the histological evidence of lymphocytic gastritis. The correlation was even better when nodules, erosions, and enlarged folds were considered. Lymphocytic gastritis has a typical endoscopical appearance consisting of nodules, erosions, and large folds predominating in the gastric body. This contrasts with non-specific gastritis, which affects the antrum and produces erosions on a flat mucosa.

We have previously described a histopathological form of gastritis characterised by a dense epithelial lymphocytic infiltration. Using this criterion for further research, this entity has been labelled 'lymphocytic gastritis'.'

Our preliminary investigations have suggested the presence of a correlation between lymphocytic gastritis and the endoscopical features of nodules, thickened rugal folds, and erosions. These features appeared unusual and different from those seen in chronic gastritis. ${ }^{23}$

The aims of the present retrospective study are to evaluate the correlation between endoscopic erosive or nodular forms of gastritis and the histological picture of lymphocytic gastritis, and to define the basic endoscopical lesions indicating a diagnosis of lymphocytic gastritis.

Methods

MATERIA L

This retrospective study is based on the cases of

Address for correspondence: Professor J Haot, Service d'Anatomie Pathologique, Cliniques Universitaires ST-LUC, Avenue Hippocrate 10-B 1200, Bruxelles, Belgium.

Received for publication 14 March 1988. gastritis diagnosed in the Department of Gastroenterology of St Luc University Hospital, Université Catholique de Louvain, Brussels, between January 1980 and December 1986.

From unselected endoscopic material of 11064 endoscopies, 192 cases fulfilled the following criteria: (a) They belonged to the category of gastritis labelled as varioliform gastritis, erosive gastritis, or aphthoid gastritis. (b) They were fully described in the endoscopical report with special reference to basic lesions and their locations. (c) Multiple biopsies (at least four) were done in body and antral regions.

Cases from which the number of biopsies was too small and where the picture corresponded to haemorrhagic or oedematous acute gastritis were excluded.

\section{ENDOSCOPICAL METHOD}

Two kinds of data were registered: (a) The diagnosis obtained by endoscopical examination: erosive, varioliform, or aphthoid gastritis. These terms refer to unusual features different from those found in chronic atrophic gastritis. 'Varioliform gastritis' was taken from the publications of Moutier et $a^{+5}$ and Lambert et al. ${ }^{6}$ 'Erosive gastritis' means according to the endoscopist, gastritis with different types of erosions and referred to Walk ${ }^{7}$ and Elta et al. ${ }^{8}$ 'Aphthoid gastritis' was coined by one of our endo- 


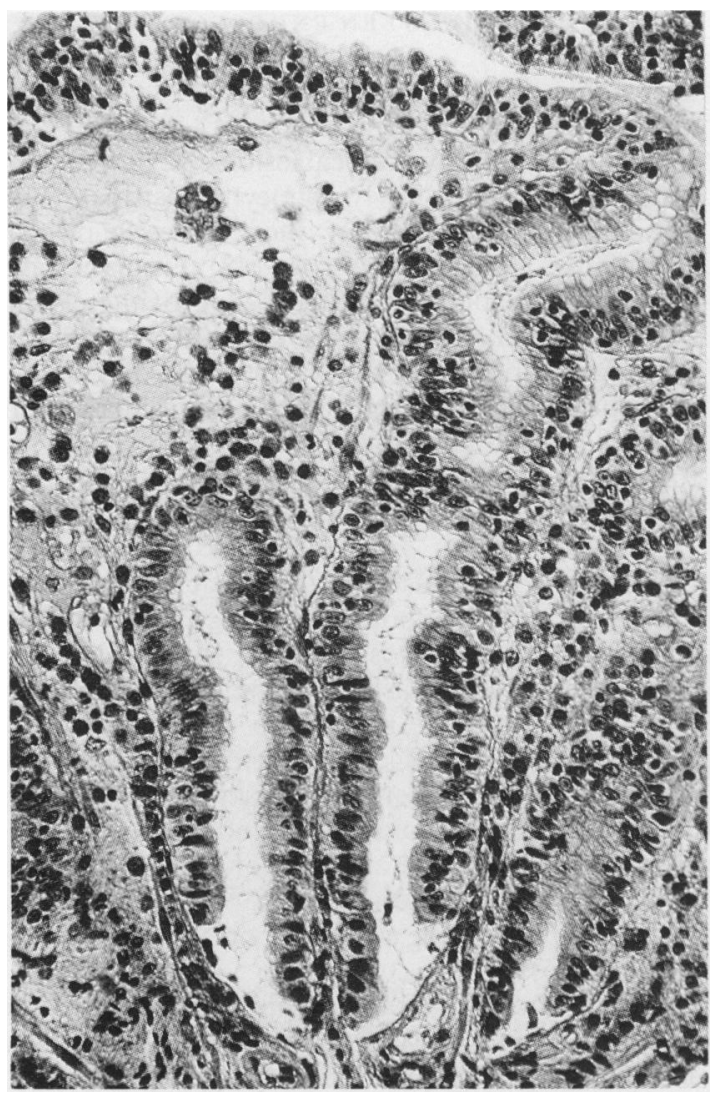

Fig. 1 Lymphocytic gastritis: Low magnification $(\times 100)$. The pits appear elongated, the lamina propria is oedematous and contains a mild amount of mononucleated cells. Numerous black dots punctuate the surface and pit epithelium.

scopists to describe a stomach with raised and ulcerated nodules (aphthoid nodules). (b) The following basic macroscopical lesions: thickened, enlarged, and moniliform (thickened folds bearing eroded nodules disposed in a string like fashion) folds not modified by complete insuflation of the stomach. Nodules appearing as rounded elevations of the mucosa. When eroded, they were most often described as aphthoid nodules. Sometimes, they culminated in a central small depression and were called umbilicated, or they were large and thus called polypoid. Erosions seen independently of the nodules - that is, erosions seen on a flat mucosa or on top of enlarged folds.

We also considered the appearance of the mucosa between the lesions and their duodenal extension. In addition other features such as ulcers and hiatal hernia were noted.

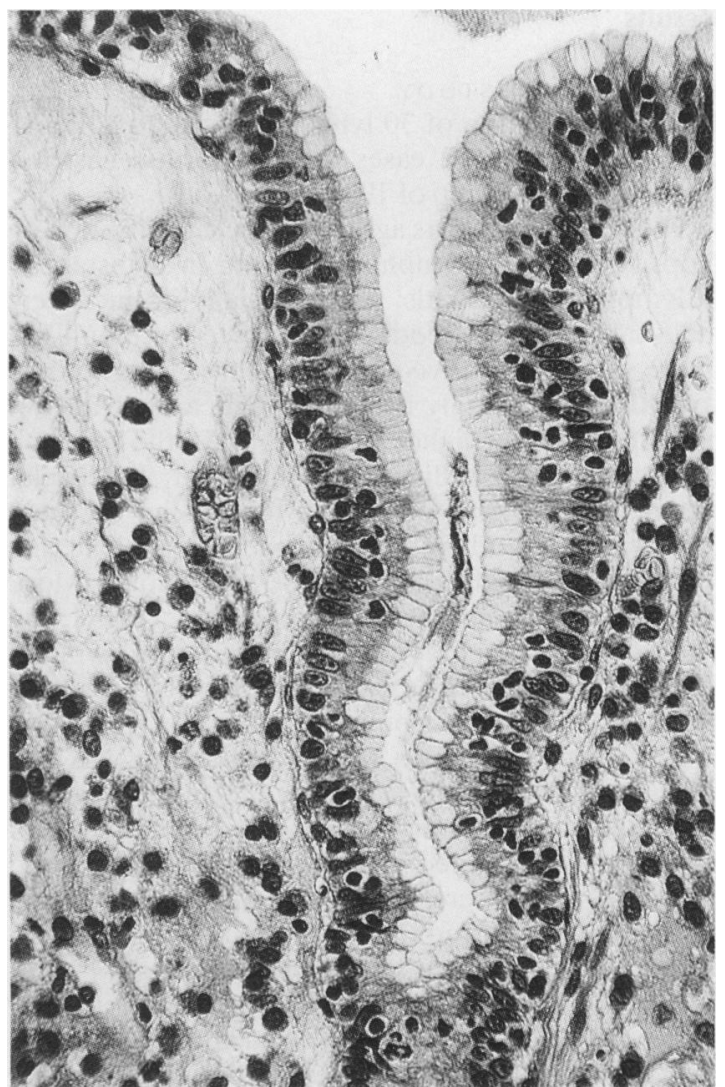

Fig. 2 Lymphocytic gastritis: Higher magnification $(\times 480)$. Numerous lymphocytes have penetrated in the epithelium. Their dark nuclei can clearly be distinguished among the epithelial cells. They are surrounded frequently by a clear rim.

\section{HISTOLOGICAL METHOD}

The biopsy specimens were oriented under a magnifying lens in gelose solution at $56^{\circ} \mathrm{C}$. After cooling, the solidified block of gelose and tissue was embedded in paraffin and $5 \mu$ slices were made. Haematoxylin and eosin saffron stain was used. The histological observations were made by two pathologists independently of each other. The diagnosis was based entirely on the presence of intraepithelial lymphocytes. The cases where intraepithelial lymphocytes were abundant were classified as lymphocytic gastritis. Based on previous studies, the ratio of 30 lymphocytes/100 epithelial cells in the areas of maximal lymphocytic concentration was used as the limit for inclusion of a case in the study. ${ }^{12}$ The cases where the number of lymphocytes was lower than this limit were considered as 'non-specific' gastritis. 


\section{Results}

HISTOLOGICAL STUDY

Using the criterion of 30 lymphocytes/100 epithelial cells we selected 92 cases of lymphocytic gastritis from the entire group of 192 observations.

The two pathologists agreed on the classification of biopsies before the lymphocyte count. In all instances of lymphocytic gastritis, and especially in the specimens taken from the body, lymphocytes accumulated in the surface and foveolar epithelium giving to that structure an intensely basophilic appearance at low magnification. At higher magnifications, the lymphocytes were clearly distinguishable from the background of epithelial cytoplasm and nuclei by their dark staining; and were surrounded by a clear rim (possibly artefactual because of retraction). Most were found at the base of the epithelium. (Figs 1,2). The concentration of lymphocytes varied from place to place, however, and one of the characteristics was its heterogeneous distribution.

Lymphocytic invasion of the epithelium was the typical hallmark of the disease, the other features being less prominent. Pits appeared slightly elongated and corrugated although without apparent decrease in their secretory activity. Lymphocytes and plasma cell infiltration of the lamina propria was present, albeit minimally in most specimens.

There was no strict parallel between the inflammatory aspect of the lamina propria and the lymphocytic infiltration of the epithelium. In the areas of erosions, the presence of polymorphs obscured the typical picture. Such an infiltrate may be heavy, invading the epithelium and forming crypt abcesses. Careful examination, however, enabled the discovery of quite numerous lymphocytes within the inflammatory infiltrate.

Conversely, the histological picture of 'nonspecific' gastritis was variable. In some cases, the lamina propria was oedematous and sometimes haemorrhagic with few inflammatory cells. In others, the picture was that which usually has been described as chronic atrophic gastritis. ${ }^{10}$

Table 1 Correlation between endoscopical and histological diagnosis

\begin{tabular}{lllll}
\hline & \multicolumn{3}{l}{ Endoscopical diagnosis } & \\
\cline { 2 - 5 } $\begin{array}{l}\text { Histological } \\
\text { diagnosis }\end{array}$ & $\begin{array}{l}\text { Varioliform } \\
\text { gastritis }\end{array}$ & $\begin{array}{l}\text { Erosive } \\
\text { gastritis }\end{array}$ & $\begin{array}{l}\text { Aphthoid } \\
\text { gastritis }\end{array}$ & Total \\
\hline $\begin{array}{l}\text { Lymphocytic } \\
\text { gastritis }\end{array}$ & 48 & 25 & 19 & 92 \\
$\begin{array}{l}\text { Non-specific } \\
\text { gastritis }\end{array}$ & 10 & 65 & 25 & 100 \\
\begin{tabular}{l} 
Total \\
\hline
\end{tabular} & 58 & 90 & 44 & 192 \\
\hline
\end{tabular}

CORRELATION BETWEEN ENDOSCOPY AND HISTOLOGY

\section{Endoscopical diagnosis}

From the 192 cases with focal lesions, 92 met the preestablished criteria for lymphocytic gastritis (Table 1). Remarkably, most of these cases had been classified as varioliform gastritis (48). From the cases diagnosed as aphthoid gastritis, approximately the same number of cases corresponded to lymphocytic and to non-specific gastritis. The larger part of the cases of erosive gastritis, had to be considered nonspecific gastritis from the histological point of view $(65 / 90)$.

\section{Type of lesions}

Figures 3 to 5 illustrate the basic endoscopical lesions. Aphthoid nodules appear as ring shaped elevations of the mucosa (Fig. 3) spread along the folds in a string like fashion in the body while being developed on a flat mucosa in the antrum. The thickened folds (Fig. 4, 5) are irregularly enlarged, moniliform and sometimes intertwined describing cerebriform circonvolutions. Under the heading erosions, we included all types of erosions without underlying nodule and seen either on a flat mucosa (Fig. 6) or appearing across or on top of enlarged folds (Fig. 5).

Table 2 shows that endoscopical features differed considerably in the two histological types of gastritis. The pathological expression of lymphocytic gastritis was the nodular appearance $(68 \%)$. Moreover, large folds, which were present in more than one third of lymphocytic gastritis cases, were found in only $2 \%$ of the non-specific cases. For both types of lesions, the

Table 2 Correlation between basic endoscopical lesions and histology

\begin{tabular}{lllll}
\hline $\begin{array}{l}\text { Histological } \\
\text { diagnosis }\end{array}$ & Nodules & Erosions & Large folds & Total \\
\hline $\begin{array}{c}\text { Lymphocytic } \\
\text { gastritis }\end{array}$ & $63(68)$ & $51(55)$ & $35(38)$ & $92(100)$ \\
$\begin{array}{c}\text { Non-specific } \\
\text { gastritis }\end{array}$ & $16(16)$ & $85(85)$ & $2(2)$ & $100(100)$ \\
\hline
\end{tabular}

( ) Results expressed in \%.

Table 3 Type of nodules observed in lymphocytic gastritis

\begin{tabular}{lllll}
\hline $\begin{array}{l}\text { Cases with } \\
\text { nodules }(n)\end{array}$ & Simple & Polypoid & Umbilicated & Eroded \\
\hline 63 & 14 & 11 & 15 & 38 \\
\hline
\end{tabular}




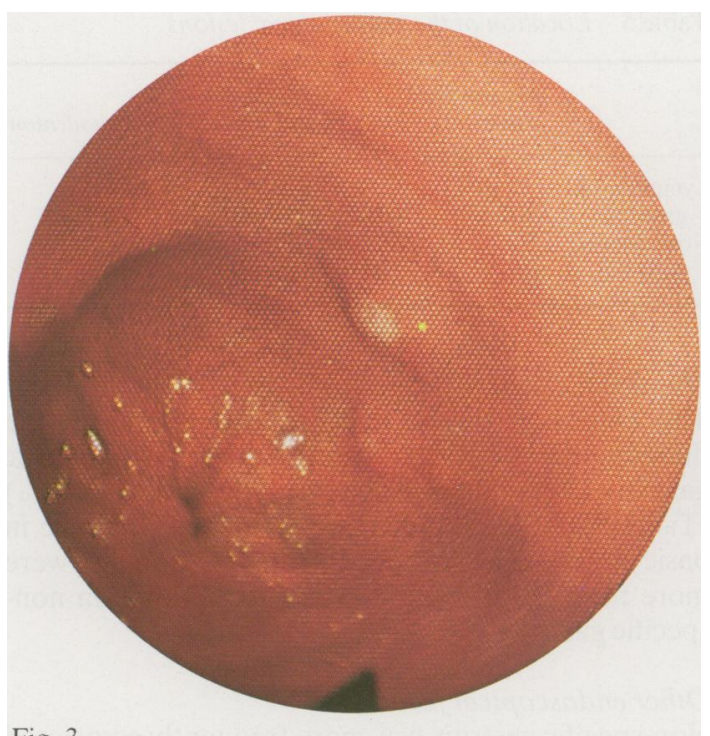

Fig. 3

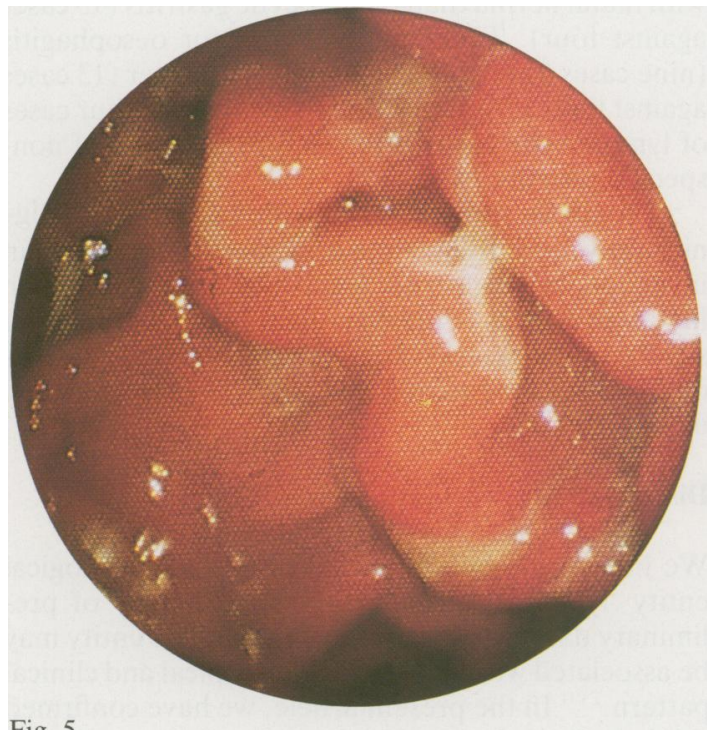

Fig. 5

statistical difference was highly significant $(\mathrm{p}<0 \cdot 001)$.

A detailed study of the types of nodules observed in lymphocytic gastritis (Table 3) showed that they may vary from simple to polypoid, umbilicated or eroded nodules. Erosions outside nodules were found in both types of gastritis but were more frequent in the 'non-specific' type. Very frequently in lymphocytic gastritis they were seen on the top of enlarged folds.

\section{Association of lesions (Table 4)}

In non-specific gastritis, the association of lesions

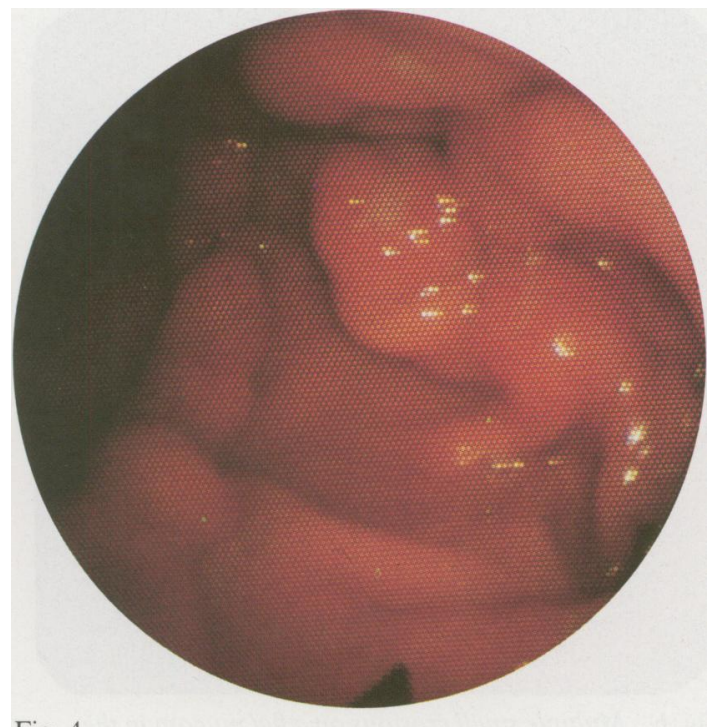

Fig. 4

Fig. 3 Disseminated nodules with erosions on the top.

Fig. 4 Cerebriform pattern of the corporeal mucosa with enlarged, thickened folds.

Fig. 5 Enlarged folds punctuated with flat variously shaped erosions.

described as basic on a macroscopical pattern - that is, enlarged folds, nodules, and erosions, was rarely observed. The combination of two types of lesions occurred in only $6 \%$ of the cases, and the association of three types of lesions was extremely rare $(1 \%)$.

Table 4 Association of basic endoscopical lesions

\begin{tabular}{llcc}
\hline & 1 lesion & 2 lesions & 3 lesions \\
\hline Lymphocytic gastritis & $55 \%$ & $27 \%$ & $18 \%$ \\
Non-specific gastritis & $93 \%$ & $6 \%$ & $1 \%$
\end{tabular}




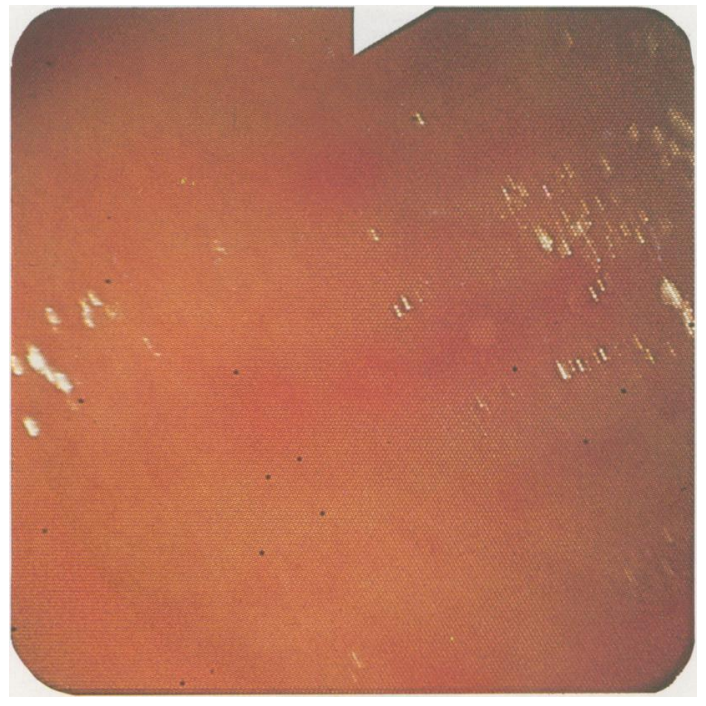

Fig. 6 Multiple small erosions on a flat mucosa in the antrum.

Lymphocytic gastritis behaved differently and was characterised by the association of two types of basic lesions in $27 \%$ of the cases and by the association of three types of basic lesions in $18 \%$ of the cases.

The most frequent associations were between large folds and nodules or between large folds and erosions.

\section{Location of the lesions (Table 5)}

Differences between the two histological types of gastritis were striking, lymphocytic gastritis being a disease extending to the entire stomach $(76 \%)$ or restricted to the body (18\%). Purely antropyloric locations were rare $(6 \%)$. In cases of diffuse gastric involvement, most basic lesions were found in the body, relative to which the antrum was spared. On the contrary, non-specific gastritis was observed nearly exclusively in the antropyloric region $(91 \%)$. Pure body locations were infrequent $(3 \%)$ and the entire stomach was involved in only $6 \%$ of the cases.

\section{ADDITIONAL DATA}

\section{Endoscopical aspects of the mucosa between the lesions}

There were no major endoscopical differences between the two conditions. In most of the cases of lymphocytic and non-specific gastritis, the mucosa appeared normal $(67 \%$ and $80 \%$ of the cases respectively) or reddish $(32 \%$ and $12 \%$ of the cases respectively). A macroscopical pattern suggestive of an atrophic gastritis was rarely observed (1\% of the lymphocytic and $4 \%$ of the non-specific gastritis).
Table 5 Location of the endoscopical lesions

\begin{tabular}{|c|c|c|c|c|}
\hline & $\begin{array}{l}\text { Antropyloric } \\
\text { region }\end{array}$ & Body region & $\begin{array}{l}\text { Whole } \\
\text { stomach }\end{array}$ & Duodenum \\
\hline $\begin{array}{l}\text { Lymphocytic } \\
\text { gastritis }\end{array}$ & $6 \%$ & $18 \%$ & $76 \%$ & $(26 \%)$ \\
\hline $\begin{array}{l}\text { Non-specific } \\
\text { gastritis }\end{array}$ & $91 \%$ & $3 \%$ & $6 \%$ & $(36 \%)$ \\
\hline
\end{tabular}

\section{Duodenal extension}

The extension of the endoscopical lesions to the duodenum was not significantly higher in non-specific gastritis $(36 \%)$ than in lymphocytic gastritis $(26 \%)$ (Table 5). In the duodenum, the same difference in basic lesions was observed - that is, nodules were more frequent in lymphocytic gastritis than in nonspecific gastritis.

\section{Other endoscopical features}

Non-specific gastritis was more frequently associated with hiatal hernia than lymphocytic gastritis (13 cases against four). The same was true for oesophagitis (nine cases against five) and duodenal ulcer (13 cases against three). A peptic ulcer was found in four cases of lymphocytic gastritis but in only one case of nonspecific gastritis.

$\chi^{2}$ Analysis showed that duodenal ulcer was significantly more frequent in non-specific gastritis than in lymphocytic gastritis while the association with hiatal hernia was borderline significant. There was no significant association between lymphocytic gastritis or non-specific gastritis and oesophagitis or peptic ulcer.

\section{Discussion}

We have previously reported on a new histological entity 'lymphocytic gastritis'. On the basis of preliminary data, we have suggested that this entity may be associated with a specific endoscopical and clinical pattern..$^{2311}$ In the present article, we have confirmed this hypothesis by means of a retrospective review of unselected material.

Lymphocytic gastritis is characterised by the presence of nodules, erosions, or enlarged rugal folds. A typical endoscopic feature of the disease is polymorphism. Indeed, although the basic lesions can be isolated there is often an association of two or three of these types of lesions. The nodules differ in type and size and exhibit various forms in the same patient for the same endoscopy. The location of the basic lesions is also characteristic. The body is the predominant site for the disease either alone or together with the antrum. This is in complete contrast with the cases of erosive 'non-specific' gastritis, which mainly 
produces erosions on a flat mucosa almost invariably in the antropyloric region.

The basic endoscopical lesions seen in lymphocytic gastritis have been reported by several authors as a picture of subacute or chronic gastritis with a rash of mucosal nodules that can be simple or eroded and can culminate in a central umbilication. In the same patients, enlarged folds have also been observed. ${ }^{+712-15}$ There is still disagreement, however, about the definition, limits, and even the very existence of this radiological and endoscopical entity, which has been labelled 'varioliform gastritis', 5011 'chronic erosive gastritis', ${ }^{78}$ or 'chronic verrucous gastritis'. ${ }^{16}$ The limits of this entity have always been quite vague, and its diagnosis uncertain because of the absence of any reliable histopathological pattern. Consequently, some well known pathology textbooks do not even mention it. " 11 Our own retrospective review reflects the difficulties met by our team of endoscopists: in spite of full descriptions of the basic lesions found in the files, the diagnosis varied between varioliform, aphthoid, and erosive gastritis.

Although a detailed and expanded discussion of the terminology used in the literature is beyond the scope of the present work, our study shows a good correlation between the diagnosis of 'varioliform gastritis' and the presence of histological features defined as characteristic of lymphocytic gastritis. There is a clear cut difference between the topography of the lesions observed in lymphocytic gastritis and non-specific gastritis. The cases of varioliform or aphthoid gastritis corresponding to the histological picture of non-specific gastritis were, as a rule, restricted (in all but nine cases) to the antropyloric region while the cases corresponding to lymphocytic gastritis were spread to the entire gastric mucosa or located in the region of the body. This is in keeping with previous endoscopical reports suggesting the existence of two different types of varioliform gastritis: one termed 'diffuse varioliform gastritis' involving the whole stomach and a second termed 'antral varioliform gastritis' restricted to the antrum. ${ }^{61+}$

We feel that the histological support provided by our previous works and by the present report will improve the diagnostic accuracy of what we may now consider a morphological entity with a macroscopic and microscopic correlate. In order to improve the understanding of lymphocytic gastritis, further work based on prospective data is mandatory. An immunological study exploring the aetiopathogenic mechanisms of the disease would also be appropriate. The presence of a large number of lymphocytes in the epithelium probably offers a suitable starting point for such an investigation. Possible models for such studies could be the coeliac disease in which there is also an increased proportion of intraepithelial lymphocytes and the lymphoepithelial complexes seen in digestive lymphomas. Nevertheless, at the present time, any comparison would only be speculative since coeliac disease involves the small intestinal mucosa ${ }^{118}$ while lymphoepithelial complexes are linked to the development of a tumoural condition of the stomach. ${ }^{19}$

We would like to thank Dr Bogomoletz, Reims, Mrs G Depresseux, Department of Rheumatology, UCL, who made the statistical calculations, Dr A Geubel, Department of Gastroenterology, UCL, Mr S Lagasse, and Mrs E Vass.

\section{References}

1 Haot J, Wallez L, Jouret-Mourin A, Hardy N. La gastrite 'à lymphocytes'. Une nouvelle entité? Acta Endoscopica 1985: 15: 187-8.

2 Haot J, Delos M, Wallez L, Hardy N, Lenzen B, JouretMourin A. Les lymphocytes intraépithéliaux en pathologie gastrique inflammatoire. Acta Endoscopica 1986; 16: 61-5.

3 Haot J, Jouret-Mourin A, Delos M, et al. Étude anatomo-clinique d'une série de gastrites chroniques caractérisées par une infiltration lymphocytaire intraépithéliale. Acta Endoscopica 1986; 16: 69-74.

4 Moutier F, Cornet A. Les gastrites cachectisantes. Les entretiens de Bichat. Paris; Expansion Scientifique, 1947; 177-8.

5 Moutier F, Martin J. Deux cas de gastrite varioliforme. Arch Mal App Dig, 1947: 36: 155-61.

6 Lambert R, Andre C, Moulinier B, Bugnon B. Diffuse varioliform gastritis. Digestion 1978; 17: 159-67.

7 Walk L. Erosive gastritis - Clinical review and analyses of twenty-seven cases. Gastroenterologia 1955; 84: 87-98.

8 Elta GH, Fawez KA, Dayal Y, et al. Chronic erosive gastritis - A recently recognised disorder. Dig Dis Sci 1983: 28: 7-12.

9 Morson BC, Dawson MP. Gastrointestinal pathology. Oxford: Blackwell, 1979.

10 Whitehead R. Mucosal biopsy of the gastro-intestinal tract. Philadelphia: Saunders, 1985.

11 Delos M, Jouret-Mourin A, Wallez L, Willette M, Mainguet $\mathrm{P}$, Haot J. Evaluation histologique d'une série de gastrites caractérisées par une infiltration lymphocytaire intra-épithéliale. Acta Endosc 1986; 16: 185-7.

12 Albot G, Leger L, Tricard A. Formations polypoïdes à sommet ombliqué de la muqueuse gastrique simulant le polyadénome. Presse Méd 1947; 3: 190-1.

13 André C, Slaoui H, Lambert R. Les maladies allergiques de l'estomac. Acta Gastroenterol Belg 1978; 41: 300-5.

14 André C, André F, Truchot R. La gastrite varioliforme: problèmes immunologiques et thérapeutiques. Acta Endosc 1982; 12: 137-9.

15 Vesin P, Kunstler E, Gouerou H, Cattan D. Gastrite 
varioliforme révélée par des oedèmes hypoprotidémiques. Sem Hôp Paris 1982; 58: 559-60.

16 Green PHR, Fevre DI, Barrett PJ, Hunt JH, Gillespie PE, Nagy GS. Chronic erosive (verrucous) gastritis. A study of 108 patients. Endoscopy 1977; 9: 74-8.

17 Corazza GR, Sarchielli P, Londei M, Frisoni M, Gasbarrini G. Gluten specific suppressor T cell dysfunction in coeliac disease. Gut 1986; 27: 392-8.
18 Jenkins D, Goodall A, Scott BB. T-lymphocyte populations in normal and coeliac small intestinal mucosa defined by monoclonal antibodies. Gut 1986; 27: 1330-7.

19 Moore I, Wright DH. Primary gastric lymphoma - a tumour of mucosa-associated lymphoid tissue. A histological and immunohistochemical study of 36 cases. Histopathology 1984; 8: 1025-39. 